\title{
In Memoriam: Juozapas Algimantas Krikštopaitis (1931-2018)
}

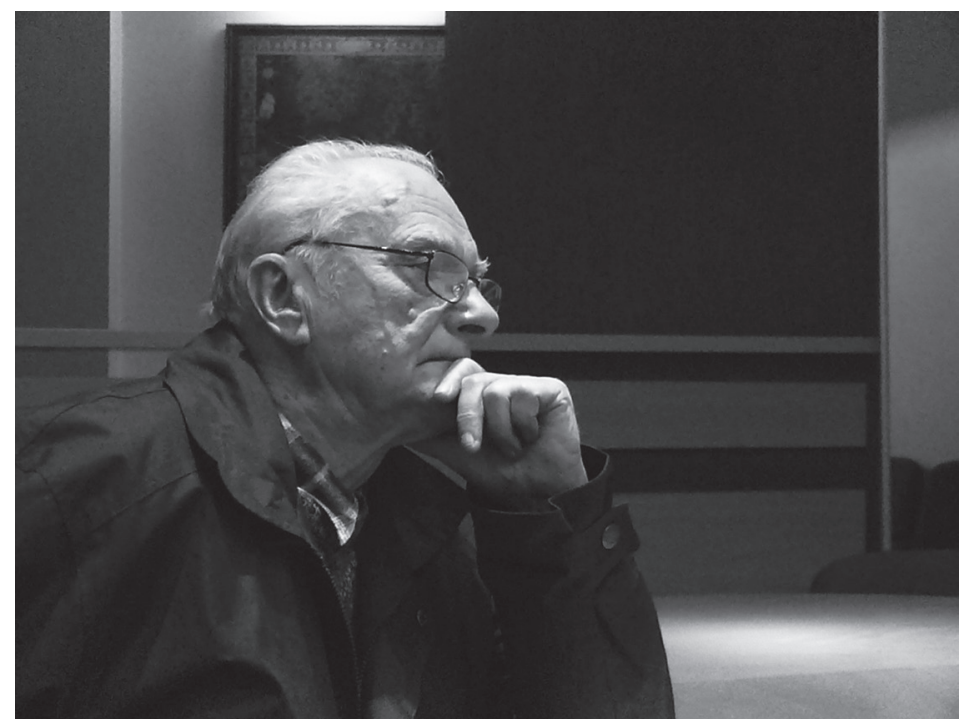

Juozapas Algimantas Krikštopaitis Photo by Gediminas Zemlickas.

The Lithuanian chemist, historian of science and philosopher, Professor Juozapas Algimantas Krikštopaitis, died in Vilnius on 10 November 2018. He was born in Kaunas on 13 March 1931. Krikštopaitis began his scientific career at the Semiconductor Physics Institute in Vilnius, where he worked from 1965-1978 doing important research on the chemistry of semiconductors.

In the early 1970s, he became interested in the history and philosophy of science and began to collaborate with the Vilnius University professor of astronomy and historian of Lithuanian science Paulius Slavenas as well as other well-known researchers in that field. Since 1978, he worked at the Institute of Philosophy, Sociology and Law of the Lithuanian Academy of Sciences, which reorganized and changed its name to Lithuanian Culture Research Institute in 2011.

Krikštopaitis was a charter member of the Senate (1989-1998) of the reestablished Vytautas Magnus University in Kaunas. He taught at Vytautas 
Magnus University, the Kaunas University of Technology and the Lithuanian University of Educational Sciences in Vilnius. He lectured and gave talks at universities and other academic institutions in Europe, Asia, and the Americas. After 1990, he was able to publish his work in the West-the United States, Italy, Finland, Sweden and Germany-and to participate in international congresses and conferences.

Krikštopaitis was head of the Lithuanian Association of Historians and Philosophers of Science from 1991, and on a rotating basis was elected chair or vice-chair of the Baltic Association of the History and Philosophy of Science. He organized many national and international scholarly conferences.

Krikštopaitis was the author of about twenty books in the fields of the history of science, philosophy, and culture studies, as well as of over 500 scientific, scholarly, and popular articles and reviews. In one of his latest books, Išmintis, atsiverianti pažinimo kelyje ['Wisdom gained on the path to knowledge', Vilnius, 2013], he summarizes his research and some of the greatest achievements in world science, positively evaluating scientific knowledge and its role in the development of civilization.

Juozapas Algimantas Krikštopaitis was a public man who fostered Lithuanian culture, actively participated in cultural events and programs, wrote a great deal for the cultural journal Naujoji Romuva and other cultural publications, and engaged with both the Lithuanian cultural elite and ordinary people in the regions. His public appearances and lectures were met with heartfelt gratitude and appreciation by his colleagues and his listeners, who admired his very sharp mind and depth of knowledge.

The Lithuanian Association of Historians and Philosophers of Science extend their deepest condolences to the family and friends of Juozapas Algimantas Krikštopaitis.

Translated from Lithuanian by Ramünas Kondratas

\section{Romualdas Juzefovičius}

